\title{
Flood Risk Index Assessment: Case Study in Lenggor River Basin, Johor, Malaysia
}

\author{
Nurul Afiqa Adila Zakaria ${ }^{1}$, Ahmad Shakir Mohd Saudi ${ }^{1,2 *}$, Mohd Khairul Amri Kamarudin ${ }^{3,4}$, \\ Muhammad Hafiz Md Saad ${ }^{4}$ \\ ${ }^{I}$ Institute of Medical Science Technology, Universiti Kuala Lumpur, 43000 Kajang, Selangor, Malaysia \\ ${ }^{2}$ Cybersecurity and System Unit, Faculty Science and Technology, Universiti Sains Islam Malaysia, 71800 Nilai, Negeri Sembilan, \\ Malaysia \\ ${ }^{3}$ Faculty of Applied Social Science, Universiti Sultan Zainal Abidin, Gong Badak Campus, 21300 Kuala Terengganu, Terengganu, \\ Malaysia \\ ${ }^{4}$ East Coast Environmental Research Institute (ESERI), Universiti Sultan Zainal Abidin, Gong Badak Campus, 21300 \\ Kuala Terengganu, Terengganu, Malaysia \\ *Corresponding author E-mail: ahmadshakir@unikl.edu.my
}

\begin{abstract}
The objective of this research is to determine the correlation of selected hydrological variables, to analyzed the significance factors influenced the occurrences of flood, to propose the flood control limit system and establish new flood risk index model in Lenggor River Basin based on secondary data derived from Department of Drainage and Irrigation (DID). Application of Chemometric technique such as Spearman's Correlation Test, Principle Component Analysis, Statistical Process Control and Flood Risk Index created the most efficient results. Result shows water level has strong factor loading of 0.78 and significant for flood warning alert system application. The Upper Control Limit (UCL) for the water level in study area is $33.23 \mathrm{~m}$, while the risk index for the water level set by the constructed formula of flood risk index consisting 0-100. The results show 20.6\% classified as High Risk Class with index range from 70 and above. Thus, these findings are able to facilitate state government to come out with a comprehensive plan of action in strengthening the flood risk management at Lenggor River basin, Johor.
\end{abstract}

Keywords: Flood risk index; Chemometric Technique PCA; SPC; Future Prediction; Lenggor River Basin.

\section{Introduction}

Increasing pressure for development in Malaysia in continuous years due to rapid population growth and urbanization has caused numerous environment-related problems including water. According to Drainage and Irrigation Department Malaysia, there are excess water (floods) and water shortage (droughts). Flood is the natural hazards lead to vital cause with a greater number of destructive events compared to any type of natural phenomenon. In fact, flood is the most prevalent of natural catastrophe, gravely disrupt the lives of human beings and the environs from the beginning of time resulting in devastation and proprietary disability. Hence, disarray the quality of life and economic growth throughout the country.

In Malaysia, 85 out of 189 total river basins were recorded prone to the recurring of flooding whilst approximately, $300,000 \mathrm{~km}^{2}$ of land area with $9 \%$ of Malaysia and $22 \%$ of the total population are located in flood vulnerable area [1]. Water is essential, but if it is overflow, exceeds its normal level and layering the surrounding land-it could afflict to any society since globally no populated area can be guarded from flooding. In Peninsular Malaysia, Johor was the second-high risk flood where its region often hit by generated series of storms of North-east Monsoon causing destructive flood in its regions.

In year 2014, there was enormous flood in the Malaysian flood history, striking the southern Malaysia includes Mersing-Kluang.
Consequently, almost of 10,000 people were placed to emergency relief centre while 21 were killed (OCHA). The occurrence of flood across the country had been described as the worst floods in decades. Accordance to that, on 2017 National Disaster Management Agency has listed Lenggor River Basin as one of the floodprone area as the pattern of flood across most of this districts has been changing, becoming more frequent and unpredictable for local communities as the causes of a flood vary according to its geographical condition as well as the location that been reserved as Central Forest Spine in National Physical Plan 2.

Therefore, the research in Lenggor River Basin is very crucial by focusing on creating the flood risk index model through the analysis of 30 years of hydrological data started from 1987-2017 using the integrated statistical analysis and application of chemometric technique. This research aimed to clarified the correlation between the selected hydrological variables, analyzed the significance factors influenced the occurrences of flood, proposed the flood control limit system and establish new flood risk index model as a flood alert warning system in Lenggor River Basin. 


\section{Materials and Methods}

\subsection{Experimental}

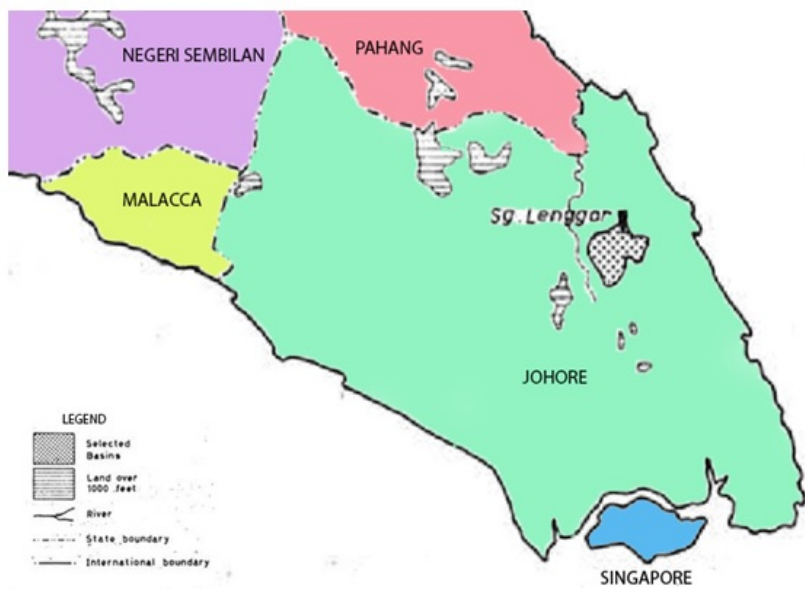

Fig. 1: Study Area and Sampling Locations

Mersing-Kluang located in the eastern Johor consisting of $838.6 \mathrm{~km}^{2}$ land with estimated population over 70,000 . Roughly, it possesses seasons which referred as monsoon season from April to November and a comparatively drier season in January until March. Lenggor River Basin in Mersing-Kluang (at $2^{0} 16^{\prime \prime} \mathrm{N} 103^{\circ}$ 44 " E) are approximately $42 \mathrm{~km}$ north-east of Johor Baharu had been the major aspect contributing to its rapid development as a growth corridor in their region [2] and accordance to the National Physical Plan 2, Lenggor River Basin had been conserved to be developed as Central Forest Spine which involved land conversions that changed the topography area $[3,4]$. Thus, due to this situation, the study area often exposed to the risk of flooding during monsoon season as there is a combination of meteorological, hydrological and socio-economic factors affects the Lenggor River basin in direct and indirect ways. In this study, the location of the monitoring station for the Department of Irrigation and Drainage is shown in Table 1 and the data were collected from 19872017.

\subsection{Principal Component Analysis (PCA)}

Application of PCA in this study is to specify on smaller scales from large numbers of variables. Variables of the Factor analysis and measured of latent construct able to determine the proportion between two factor and build the validity evidence of selfreporting ratio. Besides, it diminishes the total of variables, assesses the correlation variables to detects unidimensionality of the constructed theoretical. Generally, it addresses multicollinearity variables carried out in this study as well [5].

$Z i j=a i^{1} x j^{1}+a i^{2} x j^{2}+a i m x$

$\mathrm{Z}=$ Component score

$\mathrm{a}=$ Component loading

$\mathrm{x}=$ Measured of variable

$\mathrm{i}=$ Component number

$\mathrm{m}=$ Total variable

\subsection{Statistical Process Control (SPC)}

Time Series Analysis crucially applied in predicting water level in research area as it has been proved in efficiently analyzed the data by evaluate the process that lead to the prediction of the hydrological modeling in the future. The result generated were Upper Control Limit (UCL), Average Value (AVG) and Lower Control Limit (LCL) accordingly where it visualized from the control chart that represent each set of data's range value. The Control Chart will display the actual data vary from the historical baseline and dynamic threshold, reveal and capture trends and patterns, remarkable resource usage and becoming the best base line in hydrological studies [5].

Table 1: Location of the Monitoring Station

\begin{tabular}{|c|c|c|c|c|}
\hline Variables & Station ID & \multicolumn{2}{|c|}{ Coordinates } & \multicolumn{1}{c|}{ Location } \\
\hline Rainfall & 2237164 & $02^{\circ} 15^{\prime} 25^{\prime \prime} \mathrm{N}$ & $103^{\circ} 44^{\prime} 10^{\prime \prime} \mathrm{E}$ & Bt 42 Mersing-Kluang \\
\hline Stream flow & 2237471 & $02^{\circ} 15^{\prime} 30^{\prime \prime} \mathrm{N}$ & $103^{\circ} 44^{\prime} 10^{\prime \prime} \mathrm{E}$ & Bt 42 Mersing-Kluang \\
\hline Water level & 2237471 & $02^{\circ} 155^{\prime} 30^{\prime \prime} \mathrm{N}$ & $103^{\circ} 44^{\prime} 10^{\prime \prime} \mathrm{E}$ & Bt 42/Mersing-Kluang \\
\hline Suspended solid & 2237571 & $02^{\circ} 15^{\prime} 30^{\prime \prime} \mathrm{N}$ & $103^{\circ} 44^{\prime} 10^{\prime \prime} \mathrm{E}$ & $\mathrm{Bt} 42 \mathrm{Mersing}-\mathrm{Kluang}$ \\
\hline
\end{tabular}

Moving Range $=$ Plot: MRt

for $\mathrm{t}=2,3, \ldots, \mathrm{m}$.

where $\mathrm{MR}=$ average moving range

$\mathrm{t}=$ time

$\mathrm{m}=$ individual value

\subsection{Flood Risk Index}

A combination of multivariate analysis such PCA and SPC (TSA) has succeed in construct a flood risk index and lead to the formation of Flood Risk Model. In order for the risk index to be establish, the significant hydrological variables will be selected by an application of PCA where only the variables with highest correlation coefficient will be selected and analyzed in the next process. Then, the selected variables will further analyze by an application of SPC which resulting in the creation of UCL, ACL, and LCL. Consequently, UCL and LCL values turn out in assisting the establishment of a guideline in determining the ratio of the flood risk index in this research. Based on the principal, UCL value considered as intolerable value range for a variable and classified as a high risk index for flood [6]. The UCL value is taken for the use of formation flood risk index and will be calculated as below: $\frac{\text { UCLW }}{\mathrm{X}} \times 100=70$ (Value of High Risk index)

Based on the formula above,

UCLV = Upper Control Limit Value of variable

$\mathrm{X} \quad=$ The highest value of the data

$100=$ Risk index range from 1-100

$70=$ High Risk of Significant Value

The flood risk index formula above is construct to achieve the best risk model for flood in research area and it was standardized into 1-100 ranging of flood risk index where

70-100 = High Risk Index

35-69= Moderate Risk Index

0-34 = Low Risk Index

The Flood Risk Index adapted by The Relative Strength Index (RSI) [7]. 


\section{Results and Discussion}

\subsection{Variables Contribute to the Flood Occurrence}

From the result summarized in Table 2, it showed that stream flow and suspended solid were strongly significant and correlated with $\mathrm{p}$-values $<0.001$. However, there was also a correlation between suspended solid towards rainfall and water level with p-value of 0.031 and 0.044 . It was clear that suspended solid was one of the variables that has strong corresponds in changing the rate of stream flow and water level along with the amount of heavy rainfall in study area. On 2010, The Inter-Governmental Panel on Climate Change [8] had predicted in National Physical Plan 2, the South of Johor would eventually experience an expansion of flood prone areas and increased intensity of flooding due to the settlements and infrastructure damage along with heavy rainfall annually. Therefore, it is irrelevant to stipulate monsoon season is the only factor for flood occurrence but along with the increasing demand of development.

\subsection{Factors Contribute to Flood Occurrence}

The parameters in this research which were rainfall, water level, stream flow and suspended solid were further analyzed using Principle Component Analysis in order to identify the significant factor causes flood occurrences in Lenggor river basin. According to that, the result showed in Figure 2 summarized the most significant factors loading. F1 comprised of strong factor loading towards water level and stream flow with value of 0.78 and 0.81 respectively with the $38.99 \%$ variability of contributor to the flood occurrences while F2 with $24.96 \%$ variability shows positive moderate factor loading towards suspended solid (0.99). However, there was a negative weak factor loading towards water level and stream flow with the value of -0.04 and -0.01 .

Table 2: Correlation Coefficient between the variables

\begin{tabular}{|c|c|c|c|c|}
\hline Variables & $\begin{array}{c}\text { Rain- } \\
\text { fall }\end{array}$ & $\begin{array}{c}\text { Water } \\
\text { Level }\end{array}$ & $\begin{array}{c}\text { Stream } \\
\text { Flow }\end{array}$ & $\begin{array}{c}\text { Suspended } \\
\text { Solid }\end{array}$ \\
\hline Rainfall & 1 & 0.155 & 0.222 & 0.031 \\
\hline Water Level & 0.155 & 1 & 0.428 & 0.044 \\
\hline $\begin{array}{c}\text { Stream } \\
\text { Flow }\end{array}$ & 0.222 & 0.428 & 1 & $<0.001^{*}$ \\
\hline $\begin{array}{c}\text { Suspended } \\
\text { Solid }\end{array}$ & 0.031 & 0.044 & $<0.001^{*}$ & 1 \\
\hline
\end{tabular}

From the result, F1 came out with strong factor loading towards water level and stream flow where this result described the study area of flood occurrence was influenced by the extensive scale atmospheric circulations and anomalies that had been proved to have a significant impact on seasonal weather. According to the numerous historical flood in research area, the Northeast Monsoon brought downpour through a series of intense storms had led to the flood occurrence in study area. However, the distribution patterns along the geographical condition and location of the affected area had triggers the impact [2]. This condition can be seen in F2, as it shows the other strong factor loading triggering the flood was suspended solid. Expansion and development by human activities also contribute to the high number of suspended solid found in the study area. According to DID, Lenggor river basin area is totally forested but recently many areas have been logged over [1] due to the occurrence of development in the area as according to National Physical Plan this area has been reserved and developed to be as Central Forest Spine and involved in variety of land conversions into the agriculture sector and human settlements [3]. Definitely, due to the low lying areas and some hilly areas, the water level of the river basin rising rapidly especially after the continues heavy widespread and started to fill up the floodplain areas.

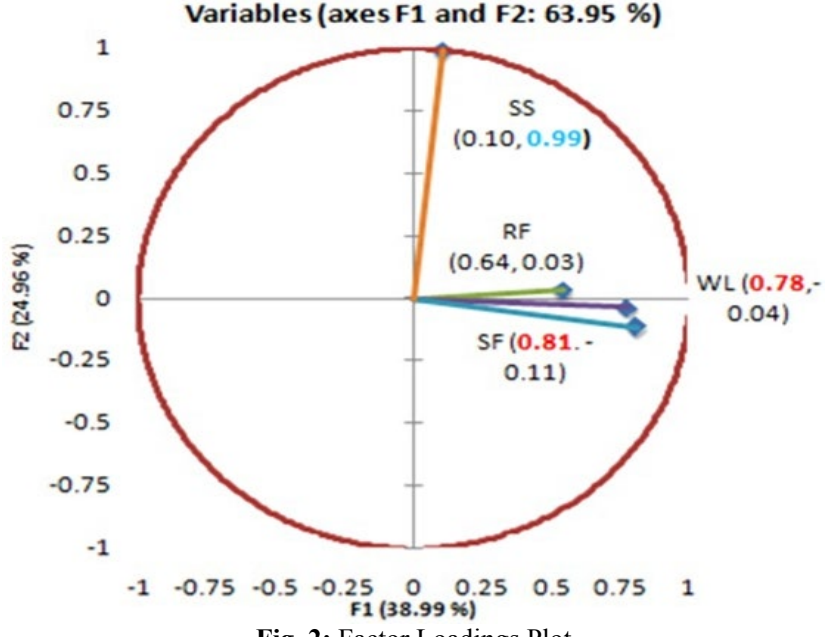

Fig. 2: Factor Loadings Plot

\subsection{Control Limit for Flood Alert Warning System}

Water level's variable was selected as the fundamental parameter for flood alert warning system as it shows the significant factor loading and the most practical to be set up as a flood alert warning system. It then further analyzed by using Statistical Process Control to set up the limitation control. The illustration of Control Chart Builder output was able to be used to set the control limit for flood alert or flood warning system as a mitigation measures in Lenggor river basin. The results consist of Upper Control Limit (UCL), Average Control Limit (ACL) and Lower Control Limit (LCL). In order to deliver a quick and right response to prevent flooding, the limitation of water level must be stated clearly. Based on Figure 3, result showed the UCL of water level is $32.33 \mathrm{~m}$ with ACL of $12.42 \mathrm{~m}$ and $11.91 \mathrm{~m}$ for LCL. The pattern results showed the significant illustration pattern were high due to directly affected by the higher intensity of rainfall during monsoon season along with the development continually occurred, the pollutants especially from non-point source generated and transported through the river basin.

This situation clearly explains how the topography area which in the low lying and some hilly areas arise rapidly the water level especially after continues heavy widespread rainfall and begin to covering the floodplain areas and change the characteristics of stream flow [8-11]. Furthermore, districts of Mersing and Kluang had facing environmental conflicts due to the higher rate of forest conversions into land for agriculture and human settlement. As such, the land use conversions around Lenggor River Basin and the development of CFS stated in National Physical Plan 2 are expected to cause Lenggor river basin experience massive flood occurrence in the near future [3]. The issues related in this study area makes necessary for developing the flood risk index model since the flood control and warning system have not been developed for many years. The UCL in this analysis is taken for the formation of risk index in the subsequent analysis.

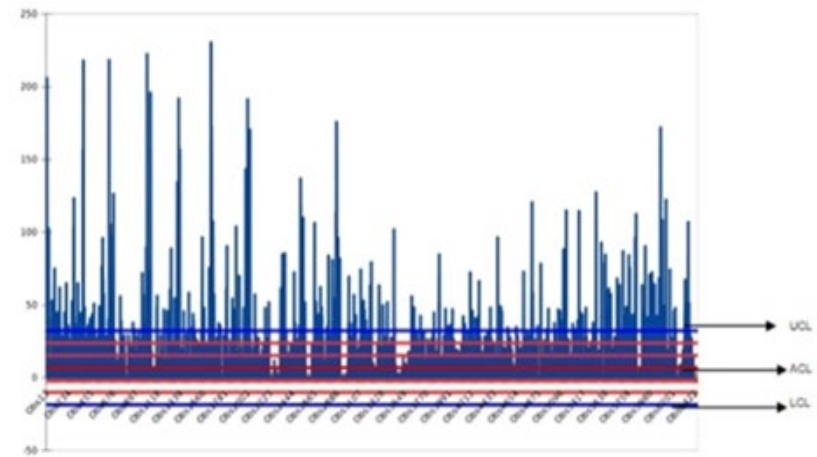

Fig. 3: Control Limit of Water Level 


\subsection{Flood Risk Index Model}

The risk analysis was conducted to further classify the actual level of flood risk for Lenggor river basin. Flood risk index range of 0 100. The risk setting for 70 and above classified as High Risk class, followed by Cautionary Zone class with range of 35-69 and 0-34 range classified as Low Risk class [5]. Therefore, the risk for the points of Lower Control Limit classified as Low Risk class, the values between Average Control Limit and Upper Control Limit classified as Cautionary Zone followed by the High Risk for the values above Upper Control Limit. Figure 4 clearly shows the illustration pattern of the flood risk index for water level according to the control limit values as stated from previous discussion. Where, the UCL for the water level is $32.33 \mathrm{~m}$ with ACL of $12.42 \mathrm{~m}$ and $11.91 \mathrm{~m}$ for LCL which directly reflects the risk zone for each values of water level in research area. Figure 5 explains the level of risk for water level in Lenggor River Basin. The result shows that $20.6 \%$ out of total result being classified as High Risk Class with a range of 70 and above risk index, $59.9 \%$ classified as a Cautionary Zone Class with a risk index from 35.69, meanwhile another $19.5 \%$ fall into low risk class with a risk index from $0-34$ Meanwhile, Flood risk reviews makes easier for the local authorities especially DID in Johor state in inspect thoroughly the level of risk incurred for an area state. Moreover, this index has been standardized with the standard value throughout the state with standard range of risk standard that applicable for each monitoring station in Malaysia would makes review of flood easy to asses and prevention measure will be strengthening and effective in future [12-14].

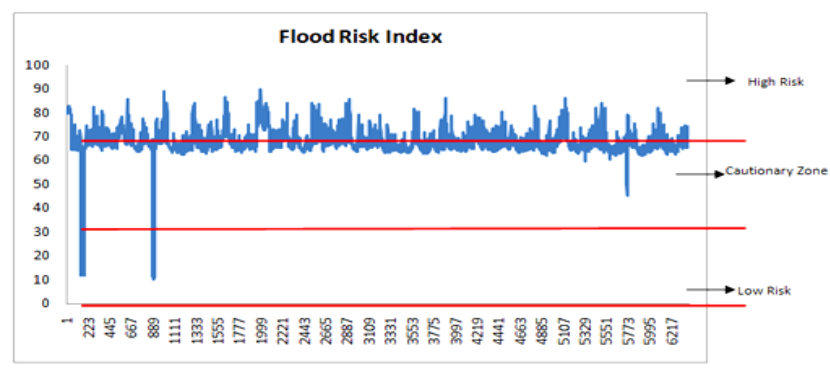

Fig. 4: Flood Risk Index

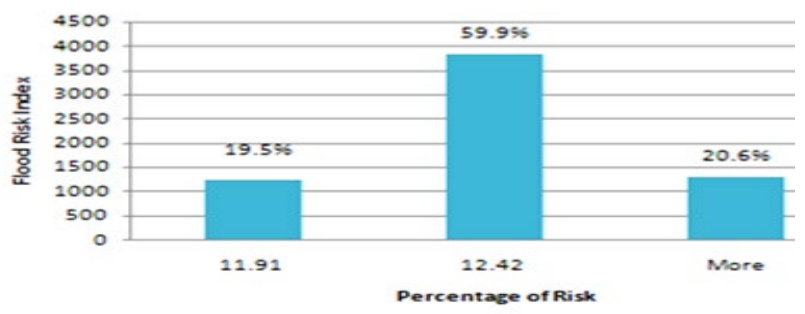

Fig. 5: Risk classification

\section{Conclusion}

This study provides a statistically proven by the application of chemometric technique which able to facilitate local authority to enhance the mitigation and prevention measure. Spearman's Correlation Test indicates the strong correlation coefficient between the hydrological variables with $\mathrm{p}$-value $(<0.05)$. Principle Component Analysis able to point out the most significant factor of variables contributed to the flooding whereby it shows the strong factor loadings towards the flood occurrence in study area influenced by Northeast Monsoon Season while human development shows positive moderate factors towards the flood occurrence. It then further analyze by Time Series Analysis which provides the limitation system for the significant variable in preventing the flood occurrences, it also accommodates local authority to come out with a more detailed plan of action based on the pattern recognition and control limit of each variables contributing to flood in study area. Following to that, the control limit that is sensitive to the changes of water level was (0.78) selected as a model of Flood Risk Index appears to facilitate local authority in set up the level of flood risk in Lenggor river basin in a clear and systematic way. Thus, the flood risk index model research area is expected to positively impact on the management of flood in rural Johor area as it could bring significant adjustment to the comprehensive flood issues especially in the rapid development country.

\section{Acknowledgement}

I would like to take this opportunity to thank the Department of Irrigation and Drainage, Malaysia for providing the research data of this study. It is also a high appreciation towards all respective co-researchers for the involvement and commitment given until the completion of this project.

\section{References}

[1] Pirani, S. I., \& Arafat, H. A. (2014). Solid waste management in the hospitality industry: A review. Journal of Environmental Management, 146, 320-336.

[2] Shafie, A. (2009). Extreme flood event: A case study on floods of 2006 and 2007 in Johor, Malaysia. Civil Engineering Department.

[3] National Physical Plan 2. (2010). Federal Department of Town and Country Planning.

[4] Toriman, M. E., Hashim, N., Kamarudin, M. K. A., Hassan, A. J. Gasim, M. B., Muhamad, A., \& Aziz, N. A. A. (2015). Assessment of water salinity model using hydrodynamic numerical modelling in estuary of Selangor River, Malaysia. Malaysian Journal of Analytical Sciences, 19 (5), 1109-1119.

[5] Saudi, A. S. M., Kamarudin, M. K. A., Ridzuan, I. S. D., Ishak, R., Azid, A., \& Rizman, Z. I. (2017). Flood risk index pattern assessment: Case study in Langat river basin. Journal of Fundamental and Applied Sciences, 9(2S), 12-27.

[6] Saudi, A. S. M., Juahir, H., Azid, A., Kamarudin, M. K. A., Kasim, M. F., Toriman, M. E., ... \& Samsudin, M. S. (2014). Flood risk pattern recognition using chemometric technique: A case study in Kuantan River Basin. Jurnal Teknologi, 72(1), 137-141.

[7] Saudi, A. S. M., Juahir, H., Azid, A., \& Azaman, F. (2015). Flood risk index assessment in Johor River Basin. Malaysian Journal of Analytical Sciences, 19(5), 991-1000.

[8] Intergovernmental Panel on Climate Change (IPC). (2007). Climate change: Synthesis report. IPC.

[9] Kamarudin, M. K. A., Toriman, M. E., Rosli, M. H., Juahir, H., Aziz, N. A. A., Azid, A., \& Sulaiman, W. N. A. (2015). Analysis of Meander Evolution Studies on Effect from Land Use and Climate Change at the Upstream Reach of the Pahang River, Malaysia. Mitigation and Adaptation Strategies for Global Change, 20(8):1319-1334.

[10] Kamarudin, M. K. A, Toriman, M. E., Sulaiman, N. H., Ata, F. M., Gasim, M. B., Muhamad, A., Yusoff, W.A., Mokhtar, M., Amran, M. A., Abd Aziz, N. A (2015). Classification of tropical river using chemometrics technique: Case study in Pahang River, Malaysia. Malaysian Journal of Analytical Sciences, 19 (5), 1001-1018.

[11] Kamarudin, M. K. A., Toriman, M. E., Wahab, N. A., Juahir, H., Endut, A., Umar, R., Gasim, M. B. (2017). Development of Stream Classification System on Tropical Areas with Statistical Approval in Pahang River Basin, Malaysia. Desalination and water Treatment, (96): 237-254

[12] Sulaiman, N. H., Kamarudin, M. K. A., Toriman, M. E., Juahir, H., Ata, F. M., Azid, A., Wahab, N. J., Umar, R., Iskandar Khalit, S., Makhtar, M., \& Arfan, A. (2017). Relationship of rainfall distribution and water level on major flood 2014 in Pahang River Basin, Malaysia. EnvironmentAsia, 10(1), 1-8.

[13] Kamarudin, M. K. A., Toriman, M. E., Wahab, N. A., Rosli, H., Ata, F. M., Mohd Faudzi, M. N. (2017). Sedimentation Study on Upstream Reach of Selected Rivers in Pahang River Basin, Malaysia. International Journal on Advanced Science, Engineering and Information Technology. 7 (1): 35-41.

[14] Saudi, A. S. M., Kamarudin, M. K. A., Ridzuan, I. S. D., Ishak, R., Azid, A., \& Rizman, Z. I. (2017). Flood risk index pattern assessment: Case study in Langat river basin. Journal of Fundamental and Applied Sciences, 9(2S), 12-27. 